\title{
延伸ポリプロピレンフィルム内の分散染料拡散 と二色性配向係数
}

\author{
山形大学工学部 增子徹 ・唐 沢幹雄 \\ 青森中央短期大学 米竹孝一郎 \\ 湖北短期大学獬島三郎 \\ DIFFUSIVE PROPERTIES OF A DISPERSE DYE IN DEFORMED \\ POLYPROPYLENE AS A FUNCTION OF DICHROIC ORIENTATION

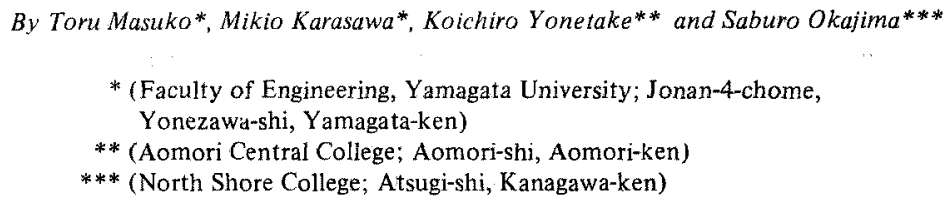

Diffusion of a disperse dye (C.I. Disperse Yellow 7 ) in polypropylene film was studied in the absence of water by a desorption sublimation method at $100^{\circ} \mathrm{C}$. The films were stretched at 130 or $140^{\circ} \mathrm{C}$ in polyethyleneglycol and subsequently heat-treated with or without restraint at $150^{\circ} \mathrm{C}$, and or immersed in cyclohexane at $68^{\circ} \mathrm{C}$. Dichroic orientation factor $\left(f_{D}\right)$ of the films dyed with the same dye was used as an orientation parameter and its effect on the diffusion coefficient $(D)$ was studied. One found that $D$ was monotonically decreased with increasing draw ratio $(v)$ or $f_{D}$, where the $D$ vs. $v$ plots were curves convex toward the $v$ axis, while the $D$ vs. $f_{D}$ plots were comparatively linear; it is suggested that the dye diffusion process is more directly associated with the orientation of the amorphous region in which the dye molecule penetrates. $D$ of the variously treated films with equal value of $f_{D}(0.37-0.40)$ decreases in the order from the swollen film to the heat-treated one with constraint, and a good linear relationship between $\log D$ and $\log E^{\prime \prime}$ (loss modulus) was observed within some of the samples including above films with equal $f_{D}$ value. It is explained that, even though the films have the same degree of amorphous chain orientation, free volume produced by segmental motions in oriented samples varies as a change of effective amorphous chain length which may be resulted in partial melting of metastable quasicrystallites by heat-treatment or swelling, and hence the diffusivity of the dye also changes among these samples.

(Received January 19, 1976)

\section{1. 緒}

繊維中に存在子る配向によって，染色時の染料拡散珄 が低下する事については，すでに多くの報告がなされて いる ${ }^{1212)}$ 。この時，配向を表舅する変数として，延伸倍 率 $^{1 \sim 6)}$, 複屈折 ${ }^{4,5)}$ ，X線配向䋆数 ${ }^{7,8,10)}$ などが用いられ るが，染料仙主として瀻維内の非晶領域に染着し，かつ この敃域の分子運動を介して桩散すると考えられるので， 配向度を表現する変数としては，直接に非晶領域に関与 するものを選定する事が望ましいであるう。

住田ら ${ }^{11}$ は，延伸交りエチレンを，篮光染料を用いて 染色与る祭，染料桩散俰数が，二色珄配向倸数の增大と 共に減少する事を見出した。住田らは，ちの理由として， 延伸による非晶領域のパッキング增大を指摘し，配向性
の增加は自由体督の低下を生ずるとして拴散係数減少の 説明を試みている。

本研究では，延伸したボリプロピレンフィルムを，種 種の条件下に処理し，C.I.Disperse Yellow 7にて染 色後、染料脱着時の抬散係数を求め，一方同染料による 可視二色性配向保数を測定して，これら両者の関保につ き検討を行った。あわせて，織維構造内の非晶分子鎖運 動性が抾散係数へ及ぼす影篦につき若干の議論を行った。

\section{2. 実験}

\section{1 供試試料と延伸}

供試試料は，チッソ（株) ポリプロピレン (PP)フィ ルムであり， $\bar{M}_{v}=2.4 \times 10^{\mathrm{b}}$ ，タクティシティー95\%(涨 滕 $n$-heptane 抽出残査)，曆さ $250 \mu$ である。このフ 
イルムを $230^{\circ} \mathrm{C}, 30 \mathrm{~kg} / \mathrm{cm}^{2}$ の条件で、ホットプレスし, 米水中に投入して無配向試料を得た。小角光散乱( $\mathrm{Hv})$ によって、このフィルム内には、球晶梏造が存在してい る事を確認した。フィルム面内の厚さ变化が少いものを 選び延伸用試料とした。

延伸は，幅 $2.5 \mathrm{~cm}$ ，長さ $7 \mathrm{~cm}$ の切片を無配向試料よ り切り出し, 手動延伸器に取り付けて，130 $\mathrm{C}$ 又は 140 ○のポリェチレングリコール(PEG)中で行った。延伸 速度は $0.5 \mathrm{~cm} / \mathrm{min}$ である。あらかじめ,フィルム表面 に標点を記し，標点間伸長をもって延伸倍率( $v)$ とした。

\section{2 熱処理並に䐧潤処理}

延伸後, 試料を延伸器に取り付けた状態で, $150^{\circ} \mathrm{C} の$ PEG浴中に浸漬し 10 分間熱処理した。この時，延伸器 フィルム取付部の間谝を調整して，緊張状熊 (I 試料) と 弛楥状態 (R試料) での二種類の熱処理を種々の延伸試 料について行った。 $\mathrm{R}$ 試料の収縮量は，各延伸倍率の約 $15 \%$ 一一定にした。熱処理後は，流水中で武料を洗浄 し、PEG寺取り除き虽乾した。

一方，2.1にて延伸しただけの試料を，PEG除去後 $68^{\circ} \mathrm{C}$ に温度制御したシク口へキサン中に浸漬し, 自由 な状態で 6 時間膨潤させた。処理後試料を風漧し, 更に $100^{\circ} \mathrm{C}, 0.003$ Tor $\mathrm{r}$ 以下の真空下で, 試䊀が烜重量上 なるまでシクロへキサンを取除いた ( 理により，ほとんどの試料は原延伸倍率 $\left(v^{\prime}\right)$ の 13〜15 乎程収樎した。ここに示されたvは，すべて処理後の最 終延伸倍率である。以上の処理を行った試料の一覽を表 1 に示す。

\section{3 染 色}

C. I.Disperse Yellow 7 は，日本化葙(株) 製力十 セットイエロー186をメタノールより数回再結晶し、佰

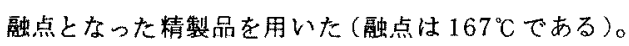
上記 I, R, S 試料上り， $1.0 \times 4.0 \mathrm{~cm}$ の切片を㚳出L。 容量 $200 \mathrm{cc}$ のステンレス製オートクレーブに入れ，次 の条件で高温染色した。

染色㵊度： $120^{\circ} \mathrm{C}$

染色時間：2 時間]

染浴濃度：15 mg dye $/ 100 \mathrm{cc}$ イオン交換水

Table 1 Preparation of samples

\begin{tabular}{|c|c|c|}
\hline Code & $\begin{array}{l}\text { Temperature of } \\
\text { drawing }\left({ }^{\circ} \mathrm{C}\right)\end{array}$ & $\begin{array}{l}\text { Temperature of } \\
\text { heat treatment }\left({ }^{\circ} \mathrm{C}\right)\end{array}$ \\
\hline $1-13$ & 130 & 150 with constraint \\
\hline $\mathrm{I}-14$ & 140 & 150 with constraint \\
\hline $\mathrm{R}$ & 140 & $\begin{array}{l}150 \text { without constraint } \\
\text { in } 15 \% \text { shrinkage }\end{array}$ \\
\hline S & 140 & $\begin{array}{l}68 \text { without constraint } \\
\text { swollen in cyclohexane }\end{array}$ \\
\hline
\end{tabular}

いず的の試料も，平衡染色される事をあらかじめ確認し た。染色完了後表面に付着した過剩の染料を，短時間风 タノール洗浄する事により除去した。染色前後において， 各試料の延伸倍济はほとんど変化しない。

\section{4 二色性配向係数の測定 ${ }^{13)}$}

回転盾光子を取り付けた島津 AQV-50型スペクトロ フォトィーターを用いて, 試料フィルムの延伸方向に平 行な場合と，垂直な場合の㖟光度（それぞれ $K_{/ 1} ， K_{\perp}$ と する)を測定した。試料表面に：シプチル・フタレート と、ジメチルフタレートを混合して屈折率をPPのそれ に近い1.500に調整した液を勧布し，石英板に試料をは さむ際の光学的接触を良好にした。染色フィルムの最大 吸収波長は， $388 \mathrm{~nm}$ であったので，これよりも長波長 領域の 450〜550 nmの笁囲で波長を変え，K//と $K_{\perp}$ をプ 口ットし，この勾配 $R$ より次式を用いて二色性配向係数 $\left(f_{D}\right)$ を得た。

$$
f_{D}=\frac{1}{C} \cdot \frac{R-1}{R+2}
$$

ここに、Cは，配向が完全となった時の $(R-1) /(R+2)$ の值であって，PP-Yellow 7 の組み合せでは，C=1.0 である事がすでに報告されて拈り ${ }^{4)}$ ，本研究では，これ を採用した。

图 1 に，K// $-K_{\perp}$ プロットの一例を示したが，直線群 は必ずしも原点を通らない。これは、スベクトル測定時 における種々の補正が不充分のためと考えられるが：二 色性配向俰数算出に関しては，勾配 $R$ を求めて(1)式を 用いると活ぼ真の $f_{D}$ に近い値を得る。

\section{5 拡散係数}

昇華脱着法により，染料の高分子内拡散保数を求めた。 この方法から，水の存在しない状態で染料应散係数を 求め得るので，应散性と高分子分子運動を対比して考え る上で都合が良い。昇華装置は，伊藤らの用いた形式 ${ }^{15}$ ) と同様であるが，冷却トラップを液体窒素に浸漬し，

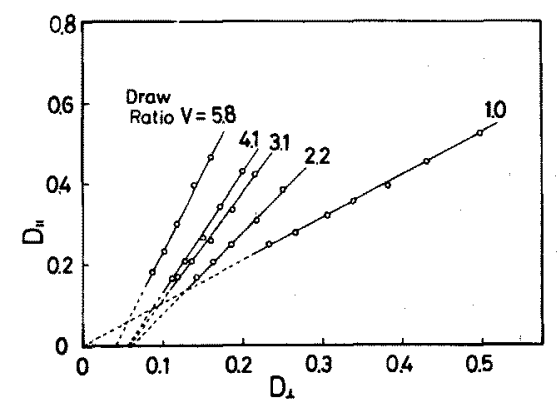

Fig. $1 D_{1 \prime}$ vs. $D_{\perp}$ plots for C. I. disperse Yellow 7 in polypropylene $(\mathrm{I}-14)$ at $25^{\circ} \mathrm{C}$ as a parameter of draw ratio. 


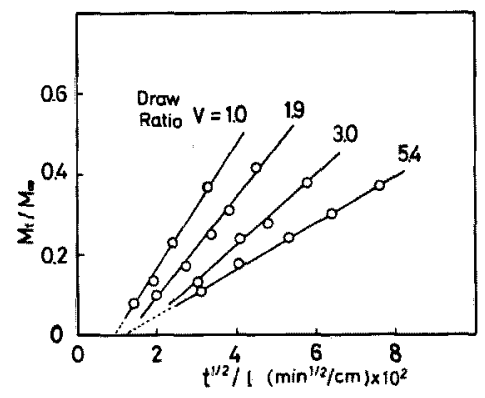

Fig. 2 Reduced desorption curves for C.I. Disperse Yellow 7 in polypropylene $(1-14)$ at $100^{\circ} \mathrm{C}$ as a parameter of draw ratio.

0.003 Torr の高真空に達する時間が 30 秒程度になるよ うにした。昇華温度は，すべての試料について $100^{\circ} \mathrm{C}$ と した。昇華時聞 $t$ におけるフィルムからの染料脱着量, 並に長特間脱着後の平衡染料脱着量をそれぞれ $M_{t}, M_{\infty}$

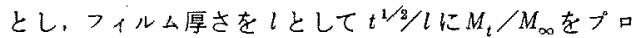
ットして得られる還元型脱着曲線の初期勾配を $I$ と寸れ ば,

$$
\begin{aligned}
& I=\frac{d\left(M_{t} / M_{\infty}\right)}{d\left(t^{1 / 2} / l\right)} \\
& D=\frac{\pi}{16} I^{2}
\end{aligned}
$$

より应散係数 $(D)$ を求㧹る。図 2 に還元型脱着曲線の 一例を示す。橫軸を脱着曲線が炀るのは，間的に系が 高真空となり得ないためである。 $M_{\infty}$ （実際に昇華し得 る染料の量) は，染色フィルムを 3 時間エタノール抽出 した値で代替したが，この值は染色フィルムを実際に一 䓢間 $100^{\circ} \mathrm{C}$ に界華脱着した平衡量と実験誤差内で一致 する事を綝返し確認した。高洫染色して得られる染色フ イルム中には，昇華脱着だけでは離脱し得ない染料も存 在するので、エタノール抽出後のフィルムを更にモノク ロルベンゼンにて抽出し, 得られた染料の量と $M_{\infty}$ を加 えて初期染着量 $M_{0}$ とした。染料濃度測定は，字べて吸 光スペクトル法によって行ったが，検量線作成時のエタ ノ一ル，モノタロルヘンゼン中における染料最大吸収波

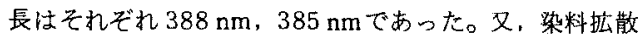
保数の濃度依存性は，その程度が僅少である ${ }^{23)}$ とてこ れを無視した。

\section{6 複屈折, 密度並に結晶化度}

延伸方向に平行及び垂直な力向の属折率をそれぞれ $n_{\mathrm{pp}}, n_{\mathrm{ps}}$ とし、フィルム厚さ方向の屈折率を $n_{\mathrm{s} s}$ として， これらを䓛光板付アッべ屈折計を用いて测定した。この 力法の詳細は，别報 ${ }^{18)}$ に述べてある。複屈折 $(\Delta n)$ は次 式加ら計算して得た。

$$
\Delta n=n_{\mathrm{pp}}-\frac{1}{2}\left(n_{\mathrm{ps}}+n_{\mathrm{ss}}\right)
$$

岡島 $5^{17)}$ により，PPの等方的属折率 $\left(n_{\mathrm{iso}}\right)$ と密度 $(\rho)$ の間には，良好な直線関係の成立する事が害験的に見出 されている。よって，密度はこの関係を用い，上記三軸 万向の屈折率平均值を $n_{\text {iso }}$ として, 次式より求めた。

$$
\frac{n_{\text {iso }}-0.9353}{\rho}=0.6294
$$

愎屈折算出の際, 屈折率を上記の関係を用いて, $0=$ $0.900 \mathrm{~g} / \mathrm{cm}^{3}$ の值に統一して補正した。

結晶化度 $(\chi)$ は, 密度から次式によって得た。

$$
\chi=\frac{\rho_{c}}{\rho} \cdot \frac{\rho-\rho_{a}}{\rho_{\mathrm{s}}-\rho_{a}}
$$

ここで， $\rho_{c}$ と $\rho_{a}$ はをれぞれPPの結晶並に非晶の密度 であって, $\rho_{\mathrm{c}}=0.936 \mathrm{~g} / \mathrm{cm}^{818)}, \rho_{a}=0.870 \mathrm{~g} / \mathrm{cm}^{819)}$ を用いた。図 3 に各種試料の○と $\chi$ を示したが，いずれ の場合も未延伸試料に比べ著しい変化任認められない。

\section{$2.7 \mathrm{X}$ 總解析之動的粘弹性}

$\mathrm{X}$ 楾発生装直は、理学電機製ロータフレックス RU-3 型に， $\mathrm{Cu}$ 対险極、 $\mathrm{Ni}$ フィルタ一老着して用い，通常

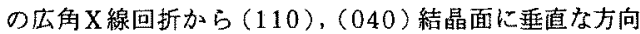
の結晶の㕕がり(d) 次のScherrerの式 ${ }^{20)}$ から求め た。

$$
d=\frac{K \cdot \lambda}{\beta \cdot \cos \theta}
$$

$こ こ て ゙$

$$
\begin{aligned}
& K: \text { Scherrer 定数 }(=0.94) \\
& \lambda: \text { 使用 X線波長 }\left(=1.542 \AA, \mathrm{CuK}_{\alpha}\right) \\
& \beta: \text { 回折強度の半価幅 } \\
& \theta: \text { 回折面の Bragg 角 }
\end{aligned}
$$

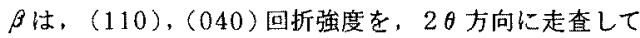
得られる回折強度分布加ら, 非晶, 空镜, 非干涉性散乱

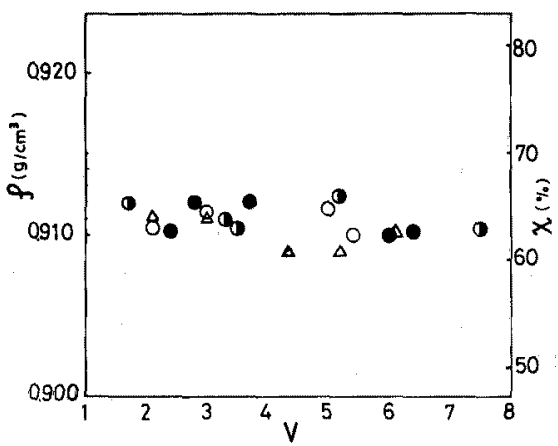

Fig. 3 Density and crystallinity of polypropylene as a function of draw ratio. ( $\triangle: \mathrm{I}-13, \bigcirc 1-14$, - $R$,
S) 
強度を差し引いて得た。

上記 X線発生装圆に，小角散乱測定台を取り付け，力 メラ半径 $50 \mathrm{~cm}$ にて角散乱像を撮影し、これより長周 期を算出した。

動的粘弹性 $\left(E^{\prime}, E^{\prime \prime}, \tan \delta\right)$ をハイイブロンDDV-II 㤠 (東洋ボールドウィン製)にて測定した。測定周波数 3.5 $\mathrm{Hz}$, 温度籁用 $-40 \sim+120^{\circ} \mathrm{C}$, 宜温速度 $1^{\circ} \mathrm{C} / \mathrm{min}$ で る。

\section{3. 实験結果}

\subsection{D対 $v$ の関係}

図4 に試料I-13 と、I-14のDに対するv依存性を 示寸。vの増大と共に, 両試料の拡散係数は単調に減少 し， $v=6$ 近辺で未延伸試料の昖散应数に比べ,ほぼ一 桁低い值を示すようになる。又, 延伸温度の影響をみる と、僅かながら $140^{\circ} \mathrm{C} の$ 場合における拡散係数が低い。 この事については，それぞれの延伸温度において生じた 配向構造が，その後の延伸㬈度よりも高温での熱処理を 加えられてもな扮残存し，広散係数の美として $D-v$ 関 係に反映するものと推察される。この事は、次節に括い て更に考察しよう。

高木と服部 ${ }^{3)}$ は，ナイロン6一酸珄染料系について， 染色時の抬散係数が，延伸倍率の増加と共に低減する事 を報告し， $v=1.6$ 近傍で $D$ は極大値を示すとしている。 彼らの説明に上ると，この極大の現われる延伸倍率にて，

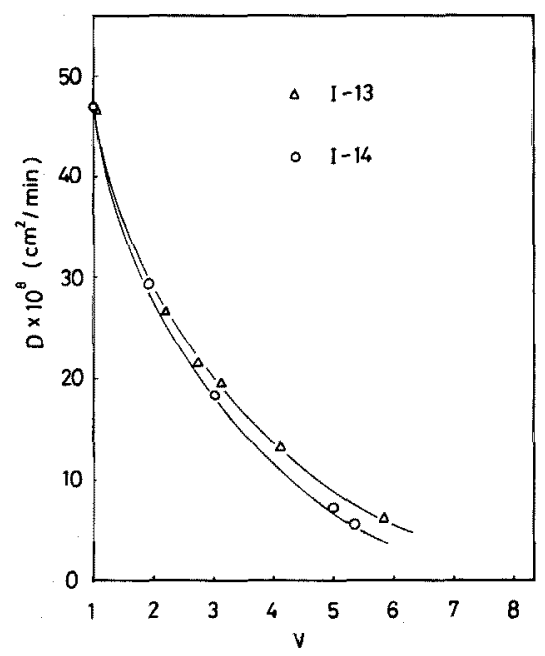

Fig. 4 Diffusion coefficient of C. I. Disperse Yellow 7 in polypropylene film as a function of draw ratio. I-13 and I-14 are stretched at 130 or $140^{\circ} \mathrm{C}$ respectively and both are annealed at $150^{\circ} \mathrm{C}$ in PEG with constraint.
㵶維中の微結晶が破壊され，その後延伸が進むにつれて 配向非晶領域内に微結晶に上る縌状構造化が発達し，非 晶分子鎖の運動性が束糐されて拡散係数が低下寸る事に なる。一方，Davis と Taylor ${ }^{\text {() }}$ は，同様にナイロン 6.6 内に㧍けるオレンジIIの桩散性を険討し，延伸倍率と共 にDが隇少する事を見出しているが，この埸合には極大 点が誑められない。

Peterlin ${ }^{21)}$ ，風息ら ${ }^{22)}$ によると，PPの場合 $v=$ $2.5 \sim 3$ 前後でラメラ型結晶の一部恃破壊し始めるとさ れている。このよらな蔽細構造に扔ける变化は，高木ら の観点よりすれば，PP内部の拡散性においても極大を 生じる延伸倍等が $v=3$ 近傍に存在する事を予測させる が，本研究に括ける $D-v$ 関俰は，vに対して単調に $D$ が滅少するのみである。一方高木“性異方性を考虑した 拡散倸数 $D_{\mu \prime \prime}, D_{\perp}$ (それぞれ緘維の長さ方向上, 半径方向 に対する払散係数)は，絩稚の構造変化を鋭敏に反映す るとしている。これについて，最近Prevorsek ら ${ }^{127}$ は、 同じようなナイロン6ー酸性染料系に拈いて， $D_{/ / 1} ， D_{\perp}$ 自体は延伸倍率に対し単調に隇少するのみであるが，同 一データを用いて $\left(D_{/ /}-D_{\perp}\right) / D_{1 /}$ 延伸倍率に対しプロ ットすると $v=3$ 近傍に極大值の現われる事を諗め, こ

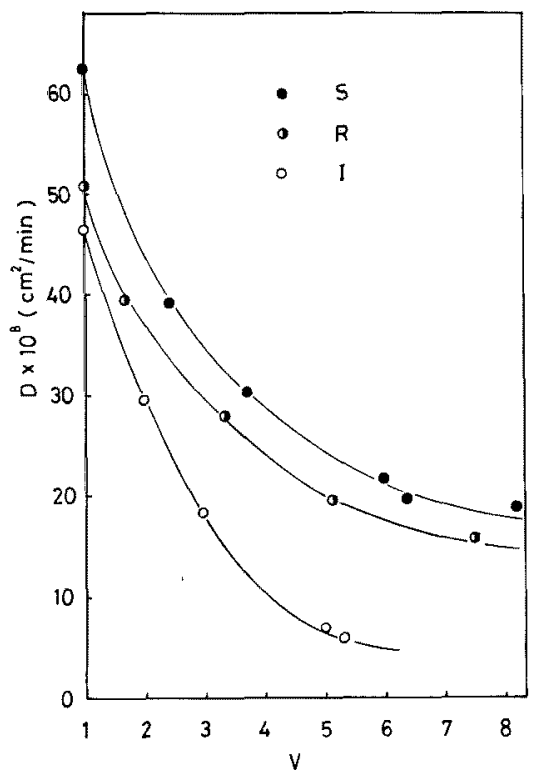

Fig. 5 Diffusion coefficient of C.I. Disperse Yellow 7 in polypropylene film as a function of draw ratio. All of samples are stretched at $140^{\circ} \mathrm{C}$, and $\mathrm{I}$ and $\mathrm{R}$ are subsequently annealed at $150^{\circ} \mathrm{C}$ with or without constraint respectively. $\mathrm{S}$ is swollen in cyclohexane at $68{ }^{\circ} \mathrm{C}$ without constraint. 
の锫率からミタロフィブリル間の军べりが始ると結論し ている。本研究において得られた㨁散係数注，フィルム の學さ万向すなわち $D_{1}$ に相当するので, Prevorsekら

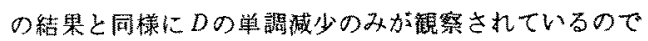
あ5。

因 5 には， I， R，S 試料のDーv関俕を示したが，こ

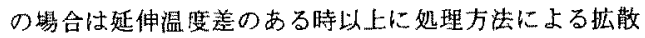
係数の相翼が影著で，司一廷伸倍密で故較するとI $\rightarrow \mathrm{R}$ $\rightarrow \mathrm{S}$ 倠に抬散係数が增大している。文， R，S試料共 にvに対する䐓向は I 同槏単調減少である。

\section{$3.2 D$ 対 $f_{D}$ の関係}

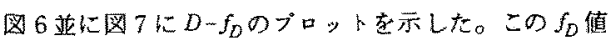
は， $25^{\circ} \mathrm{C}$ で測定されているが，拡散係数は $100^{\circ} \mathrm{C}$ にお ける承測值である。二色性の鼬度依存性を中山ら

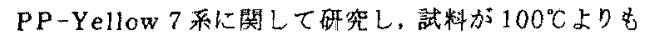
高鼬にて熱越理された場合，室温と $100^{\circ} \mathrm{C}$ に㧍ける二色 性值にほとんど差を生じていない事を見出しており，乙 の結果から判断して図6.7の様に测定温度の異る二变 数間のプロットを行っても妥当であると考えた。

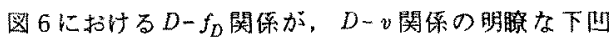
型とは異り，执散係数がより直線的に $f_{D}$ と共に减少す

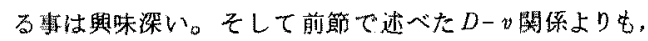
I-13とI-14試料間には画然とした差が譛められる。 これについて，染料加非晶領城中を墌散するとの立场加 らみると，延伸倍䍤よりも，二色性配向保数の力か非晶

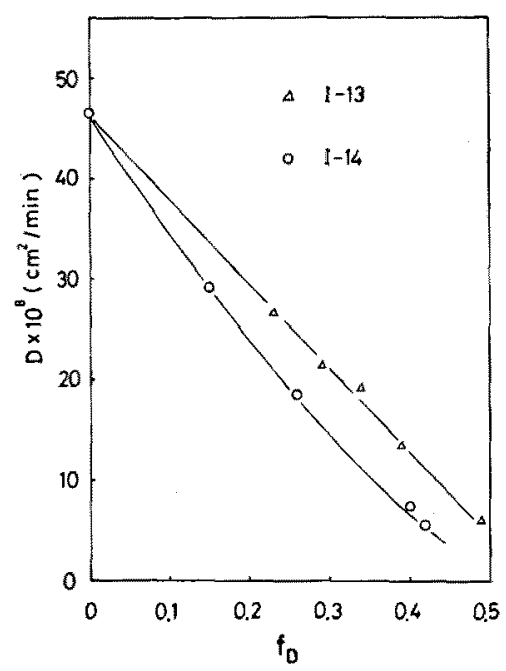

Fig. 6 Diffusion coefficient of C.I. Disperse Yellow 7 in polypropylene film as a function of dichroic orientation factor. $\mathrm{I}-13$ and $\mathrm{I}-14$ are stretched at 130 or $140^{\circ} \mathrm{C}$ respectively and both are annealed at $150^{\circ} \mathrm{C}$ in $\mathrm{PEG}$ with constraint.

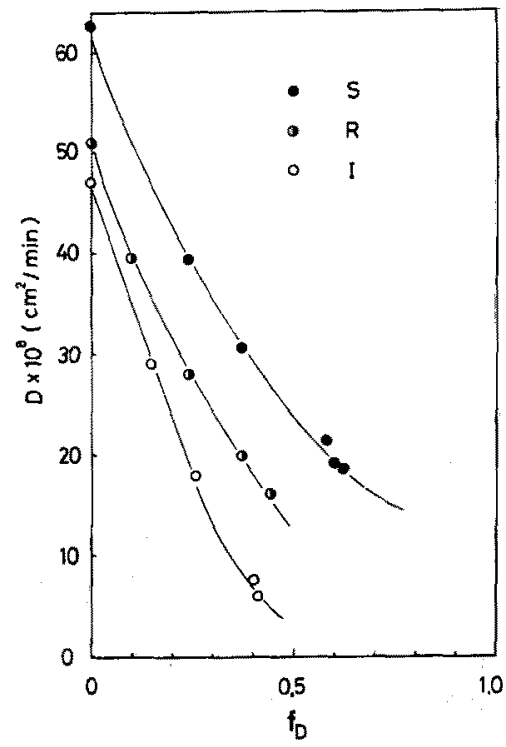

Fig. 7 Diffusion coefficient of C.I. Disperse Yellow 7 in polypropylene film as a function of dichroic orientation factor. All of samples are stretched at $140^{\circ} \mathrm{C}$, and $I$ and $R$ are subsequently annealed at $150^{\circ} \mathrm{C}$ with or without constraint respectively. $\mathrm{S}$ is swollen in cyclohexane at $68^{\circ} \mathrm{C}$ without constraint.

状態変化に対応して拉散绿数の減少する様子を鋭敏に反

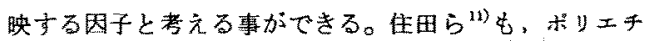

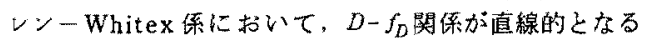
事を報告して拉り，彼らと著者らの拡散係数測定方法は 翼るものの，その㑯向は比较的良く一致する。図7のI， $\mathrm{R} ， \mathrm{~S}$ 試料系列においても，Dは $f_{D}$ の增大と共にほぼ直 線的に低下する事加示されている。Dか， I $\rightarrow \mathrm{R} \rightarrow \mathrm{S}$ 系 列の順に增加する傾向は。图5における場合と同様であ 分。

これらの事事に対し，一般論として分子配的による非 晶領域のパッキング增大が，非晶分子鎖の運動性を低下 させ，自由体精が减少する結果拡散保数が低下する ${ }^{11,26}$ と推定して良いであらう。この非晶バッキングは，非毘 領域全体の充塓が平均的に增大する場合上，局部的に分

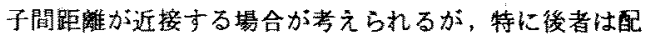
向非晶項域の熱力学的に不安定な凝集状態一準結晶の概 念に連結されるであらう。延伸ポリプロピレンの熱解析 (DTA)によって，金網 $5^{28)}$ 忙庙X線回折には大きな 影響を及ぼさないが，延伸温度又は熱処理温度に対応し

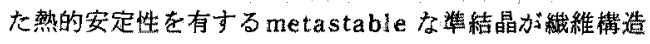
内に存在寸ることを見出した。そして延伸試料を舆緊張 
状態で熱処理した場合は $130^{\circ} \mathrm{C}$ 以下で，又緊張状態で熱 処理した場合 $150^{\circ} \mathrm{C}$ 以下でこのmetastableな集結晶は 発生しにくくなる事を報告している。更に田中ら ${ }^{\text {a() }}$ は， PP（著者らと全く同し原試料）を $140^{\circ} \mathrm{C}$ で熱延伸し，熱 的検討（DSC）を加えた結果，延伸倍率が增大寸るに伴 ってその融解ビークはブロードになり，又その形状も椱 雑になる事を報告している。このような現象も matas table な雀結晶が，PP の延伸配向構造中に存在する事 を香定するものではない。文彼らの結果に倣いて，v $=10$ 程度まで密度が大幅に上算していない事も示され ていてこのような隼結晶の存在は密度にほとんど影響 しないと想定される。

本研究に扔いては，熱解析を行っていないけれども， 上記研究者らの結果より判断して，延伸温度並に熱処理 温度に相当した熱力学的に不安定な準結晶を配向非晶領 域に想定して大過ないであるう。そして，延伸配向と共 に準結晶数が增加し，これらを結節点として非晶領域内 に絧状楧造が楧成されるとするならば，結節点の增加は 非晶分子鎖長を短樎して，その熱振動、熱回転運動を束 綁し，自由体皘を低下せしめ，結果として厸散保数は減 少すると考えられる。

害多村ら ${ }^{27}$ は，熱処理条件を変えた延伸ポリエステル 内の染料昖散係数と，X線小角散乱強度に良好な正の相 関のある事索認力、非晶領域内に中間的凝集状態*1上り 生じた網状構造を仮定してこれを解积している。彼らの 堭合，熱処理によって密度は増加しているが，その拡散

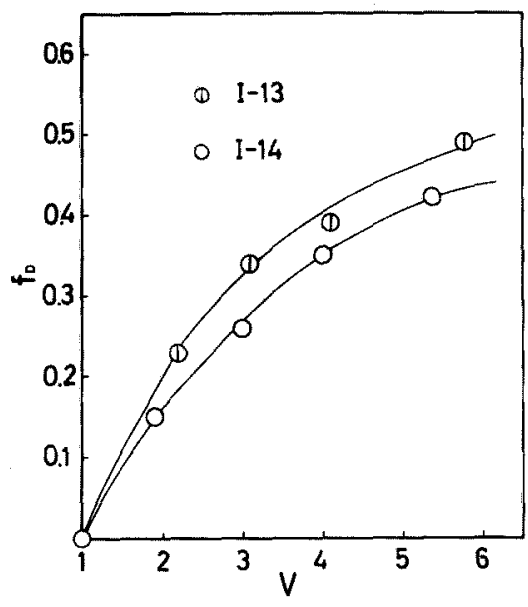

Fig. 8 Dichroic orientation factor of C.I. Disperse Yellow 7 in polypropylene film as a function of draw ratio. $\mathrm{I}-13$ and $\mathrm{I}-14$ are noted in the caption of Figure 6.

*1著者らの言ら準結晶に相当すると考えられる。
性に対する考え方は著者らと同一のものである。

以上の観点より，延伸温度莯低い時に，払散係数が大 きくなる(图 6) 理由を考察してみよう。これら全ての 試料密度が，延伸温度，延伸倍垶にかかわらずほとんど 一定である事から，非晶量が著しく増えて拡散係数を大 きくしているとは考え難い。一般に，低温での延伸は， 分子配向性を增加させるが，図8に示したように。この 場合も I-13 試料は I-14 試料よりも染着颃域の配向性 は大きい。両者共に固定熱処理であるがゆえに，熱処理 前後における非晶配向性の変化は少いと考えられる。そ して，延伸温度が低く，配向性の高い非晶状態では，延 伸温度の高い場合に比べ形成される準結晶の熱的安定度 は低く，かつその数は多いであろう。これらを同一熱処 理温度にて緊張熱処理すれば，準結晶の部分融解に基つ く結節点解離は低温延伸程著しく，したがって結節点間 非晶分子鎖長は大きくなる。熱処理後に室温へ冷却する 際の準結晶形成は，金網らの指摘するように $150^{\circ} \mathrm{C}$ 祭 張熱処理であるため生じ難くなり，非晶分子鎖長は保存 されて，自由体積増加即ち拡散保数增大が説明されよう。

一方，同一延伸温度にて得られた I, R， S 試料は，収 樎熱処理，钐潤処理の過程を経ているのて， $f_{D}$ を同じ くしても細構造が变化して拡散係数に関与している可 能性がある。そこで，以下に構造特性を吟味してみる。

$3.3 f_{D}$ の等しい試料の構造因子並に物性の比較 ほぼ等しい $f_{D}$ 値を有するが，その拡散係数は異るI， $\mathrm{R}, \mathrm{S}$ 試料（图 7 における $f_{D}=0.37 \sim 4.0$ の試料）につい て敬細構造特性を一覧したのが表 2である。及、これら の試料の広角X線回折図形並に小角 X線散乱像江図 9 に

Table 2 Characteristics of sample I, R, S

\begin{tabular}{|c|c|c|c|}
\hline sample & $\mathrm{I}$ & $\mathrm{R}$ & $\mathrm{S}$ \\
\hline \hline$v$ & 5.0 & 5.2 & 3.7 \\
\hline$v^{\prime}$ & 5.0 & 6.0 & 4.2 \\
\hline$f_{D}$ & 0.4 & 0.37 & 0.37 \\
\hline$D\left(\mathrm{~cm}^{2} / \mathrm{min}\right)$ & $7.5 \times 10^{-8}$ & $19.5 \times 10^{-8}$ & $30.7 \times 10^{-8}$ \\
\hline$a\left(\mathrm{~g} / \mathrm{cm}^{3}\right)$ & 0.9109 & 0.9112 & 0.9110 \\
\hline$\chi(\not / 0)$ & 63.7 & 64.1 & 63.8 \\
\hline$\Delta n_{\mathrm{pp}}$ & $27.8 \times 10^{-8}$ & $29.1 \times 10^{-3}$ & $23.7 \times 10^{-8}$ \\
\hline$T_{g}\left(\tan \delta,{ }^{\circ} \mathrm{C}\right)$ & 4 & 3 & 3 \\
\hline$d(\AA) d_{(110)}$ & 102 & 105 & 105 \\
\hline$d_{(010)}$ & 105 & 96 & 108 \\
\hline$E_{100}^{\prime}\left(\mathrm{dyn} / \mathrm{cm}^{2}\right)$ & $10.3 \times 10^{8}$ & $8.0 \times 10^{\mathrm{g}}$ & $5.4 \times 10^{8}$ \\
\hline$E_{100}^{\prime \prime}\left(\mathrm{dyn} / \mathrm{cm}^{2}\right)$ & $7.3 \times 10^{8}$ & $5.0 \times 10^{8}$ & $4.3 \times 10^{8}$ \\
\hline$L_{\mathrm{p}}(\AA)$ & 220 & 220 & 216 \\
\hline$M_{0}(\mathrm{mg} / \mathrm{g})$ & 4.1 & 4.3 & 4.4 \\
\hline$M_{\infty}(\mathrm{mg} / \mathrm{g})$ & 3.3 & 3.8 & 4.0 \\
\hline$M_{\infty} / M_{0}$ & 0.81 & 0.88 & 0.91 \\
\hline
\end{tabular}


I
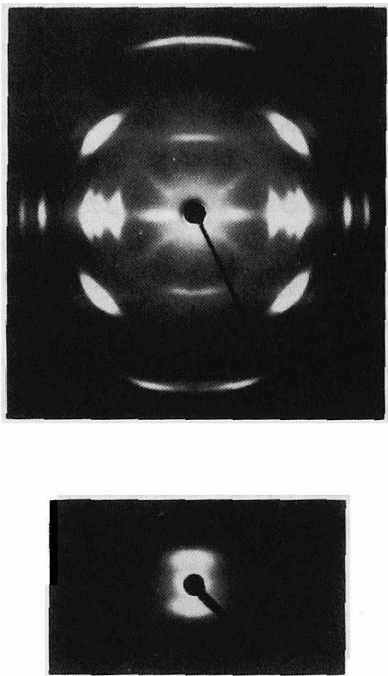

R
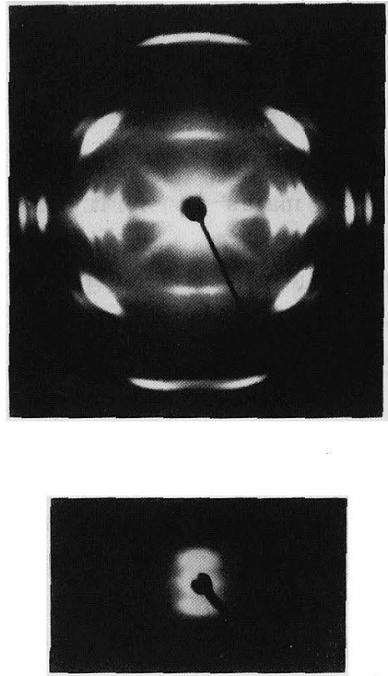

$\mathrm{S}$
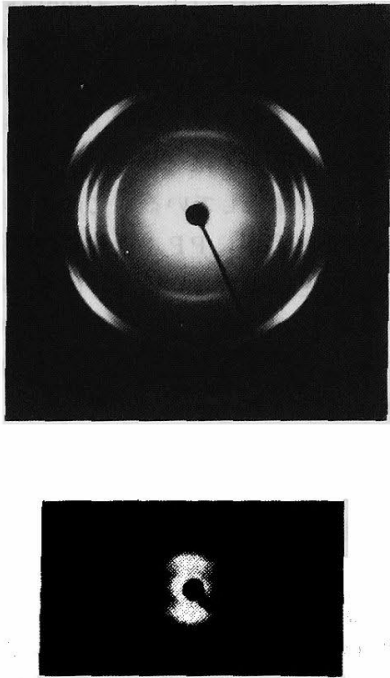

Fig. 9 Wide angle $x$-ray diffraction and small angle $x$-ray scattering patterns of sample $I, R$ and $S$ $\left(f_{D}=0.37-0.40\right)$. Drawing direction is vertical.

示した。これからわかるように, 結晶化度, $\mathrm{c}$ 軸に直交 する方向の結晶の広がり, 長周期, 主分散温度位置 (カ ラス転移点に対応する) は，ほとんど三試料間に差を生 じていない。X線小角散乱像から判断すると，ボイド散 乱のない事からこれらの試料中には，マクロな空吵は存 在しないと考えられる。これは未延伸試料と比べ, 染着 量が著しく増加しない事からも支持される。長周期が誤 差内で等しいことから, 熱処理しても, ラメラの厚化は 生じていないと言える。認められる差巽は，I， R試料 に比べて S試料は結晶配向性が低下している事(図9)， $E_{100}^{\prime}$ と $E_{100}^{\prime \prime}$ がI， R，Sの順に低下している事， $M_{0}$ 並に $M_{\infty}$ が若干ではあるがその順で逆に増大している事であ る。複屈折の差は， $f_{D}$ を同じくしているので, 結晶配 向の変化に基づくものであろう。結晶粒子の大きさがほ とんど等しい場合, その配列に多少の乱れがあっても著 しく染料の払散性に影響を与えないであろうからここ では特に非晶の運動性に関連のある $E_{100}^{\prime \prime}$ と，拡散係数の 関連について考察してみる。藤田 ${ }^{28)}$ は, 高分子中のセグ メント運動と、ペネトラント拡散性を結合する理論の中 で, 無定形高分子について次の式を提唱し, その験証を 行った。

$$
\log \left(D_{0} / R T\right)=A-B d \log \eta
$$

$D_{0}$ : 濃度 0 一外挿された拡散係数

$A, B d:$ 定数, 但 $ᄂ B d=0.7 \sim 0.9$ 程度 $\eta:$ 粘性係数
$T:$ 絶対温度

$R:$ ガス定数

藤田に習い, J.P.Bellは, 結晶性ポリマーについて, この理論を適用する事を試み， $\eta$ を $E^{\prime \prime}$ と置き換えて， イロン $66^{29)}$, ポリエステル ${ }^{30)}$ ，ポリアクリロニトリル について実験的検討を加えた結果， $B d=2.0 \sim 4.5$ 程度

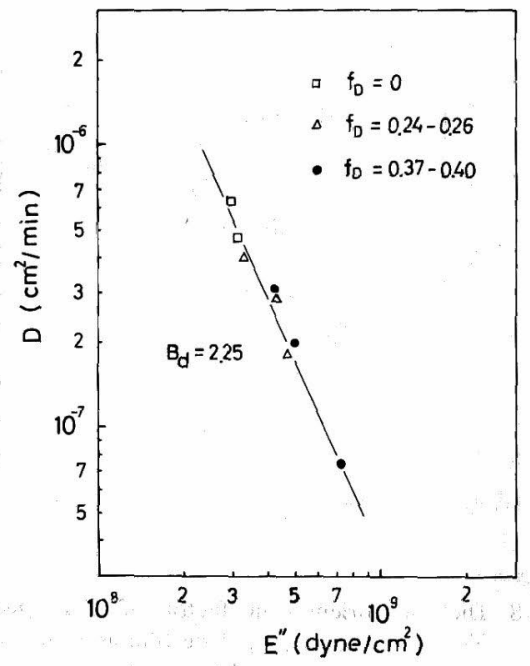

Fig. $10 \log D$ vs. $\log E^{\prime \prime}$ plot as a parameter of $f_{D}$. From the slope of line, one obtains, $B_{d}=2.25$. 
Table 3 Estimation of $B_{d}$ by experimental data.

\begin{tabular}{|c|c|c|c|c|}
\hline polymer & penetrant & $B_{d}$ & author & note \\
\hline $\begin{array}{l}\text { polymethyl- } \\
\text { acrylate }\end{array}$ & benzene & 0.86 & H. Fujita ${ }^{28)}$ & \\
\hline $\begin{array}{l}\text { polyethyl- } \\
\text { acrylate }\end{array}$ & benzene & 0.714 & H. Fujita ${ }^{28)}$ & \\
\hline $\begin{array}{l}\text { polymethyl- } \\
\text { methacrylate }\end{array}$ & $p$-nitroaniline & 0.847 & Y. Kobayashi ${ }^{32)}$ & $\begin{array}{l}\text { desorption } \\
\text { sublimation }\end{array}$ \\
\hline \multirow{2}{*}{ polyurethane } & $p$-nitroaniline & 0.97 & \multirow{2}{*}{$\begin{array}{l}\left.\text { S. Okajima }{ }^{33}\right) \\
\text { et al. }\end{array}$} & \multirow{2}{*}{$\begin{array}{l}\text { desorption } \\
\text { sublimation }\end{array}$} \\
\hline & p-aminoazobenzene & 1.00 & & \\
\hline Nylon 66 & C.I. Acid Red I & 4.5 & $\begin{array}{l}\text { J.P. Bell }{ }^{29)} \\
\text { et al. }\end{array}$ & D in water \\
\hline $\begin{array}{l}\text { polyacrylo- } \\
\text { nitrile }\end{array}$ & C.I. Basic Blue 22 & 2.0 & $\begin{array}{l}\text { J.P. Bell }{ }^{31)} \\
\text { et al. }\end{array}$ & $D$ in water \\
\hline polypropylene & C.I. Disperse Yellow 7 & 2.25 & present study & $\begin{array}{l}\text { desorption } \\
\text { sublimation }\end{array}$ \\
\hline
\end{tabular}

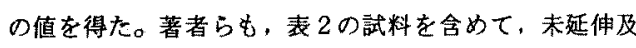

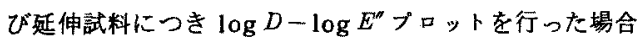
を図10に示した。その直線性は良好であって，勾配よ り $B d=2.25$ の值を得た。各種の配向状態にある試料, 並に収縮熱処理や膨潤処理を行った試料について，同一 のBd值が得られたので，こ机らの陚料内で自由体皘が 形成する所の染料拡散に必要な臨界の孔体䅡が揖およそ 等しいと言えるであるう。更に $B d は$ ，执散物質が拡散 を開始するに必要な最小の臨界体積と，七グメントがミ クロブラゥン運動を開始するのに必要な最小の臨界体䅡

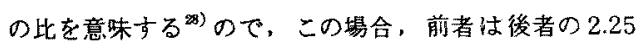
倍程となる。

これに関連して、各䅜の方法により寒験的に定められ た $B d$ の值を表 3 に示す。有機溶媒で $B d=0.7 \sim 0.86^{28)}$, モデル染料 ( $p$-nitroaniline, $p$-aminoazobenzene) で $B d=0.85 \sim 1.0^{32 \sim 39)}$, 染料分子で $B d=2.0 \sim 4.5^{20,31)}$ 程度となっていて、それぞれベネトラント分子体皘の大 きさが反映していると考えられる。本研究で得られた $B d=2.25$ は，J.P.Bell らのアクリル瀻維一塩基性染料 系に括ける $B d=2.0^{31)}$ に近い。

一方，これら $f_{D}$ を等 LくLた I, R, S 試料の $25^{\circ} \mathrm{CK}$ おける四塩化炭素平衡膨潤量（試料浸漬後 24 時間でい ずれも平衡に達する事を確認した）を求め。次のFloryRehnerの式 ${ }^{\text {*) }}$ 加非晶鎖分子量 $\left(\bar{M}_{c}\right)$ t算出し，表 4 に一筧した。

$$
\begin{aligned}
\ln a_{1}= & \ln v_{1}+v_{2}+\chi_{12} v_{2}^{2} \\
& +\left(\rho_{2} V_{1} / \bar{M}_{c}\right)\left(\langle\alpha\rangle_{0}^{2} v_{2}^{1 / 3}-\left(2 v_{2} / f\right)\right)
\end{aligned}
$$

\section{$a_{1}$ : 溶媒活動度}

$v_{1}:$ 平衡膨潣ポリマー内での溶媒体積分率

$v_{2}$ : 同上内でのポリマー非晶部の体積分率

$\rho_{2}:$ ポリマー非晶密度 $\left(\rho_{2}=0.870 \mathrm{~g} / \mathrm{cm}^{\mathrm{B}}\right)$

$V_{1}:$ 四塩化能秦のモル体積
Table 4 Swelling data of sample I, R, S. The specimens correspond to Table 2.

Equilibrium swelling with carbon tetrachloride was attained at $25^{\circ} \mathrm{C}$ and after $24 \mathrm{Hr}$ immersion.

\begin{tabular}{|c|c|c|c|}
\hline Sample & $\mathrm{I}$ & $\mathrm{R}$ & $\mathrm{S}$ \\
\hline $\begin{array}{c}\text { Density } \\
\left(\mathrm{g} / \mathrm{cm}^{3}\right)\end{array}$ & 0.9109 & 0.9112 & 0.9110 \\
\hline Crystallinity & 63.7 & 64.1 & 63.8 \\
\hline Solvent $(\mathrm{g})$ & 0.152 & 0.172 & 0.262 \\
\hline Polymer $(\mathrm{g})$ & 0.814 & 0.793 & 0.717 \\
\hline$\nu_{2}$ & 0.522 & 0.501 & 0.435 \\
\hline$x_{12}$ & 150 & 166 & 234 \\
\hline$M_{c}$ & & \\
\hline
\end{tabular}

$\bar{M}_{G}:$ 架橋点間平均非晶鎖分子量

$\langle\alpha\rangle_{0}$ : 膨潤と末膨潤ポリマーに対寸る平均末端間距離 比

$f$ :架橋点に括ける分㿬度

$\chi_{12}$ : 高分子一溶媒間相互作用パラメーター

ここでは，結晶並に準結晶を非晶領域内に形成された 架橋点と想定し，(8)式が延伸ポりマーにも適用できる ものとしている。更に， $\bar{M}_{c}$ 計算の際， $\langle\alpha\rangle_{0}^{2}=1,2 v_{a} / f$ $\ll\langle\alpha\rangle_{0}^{2} v_{2}^{1 / 3}$ と仮定し， $\chi_{12}$ は落合ら ${ }^{35\rangle}$ がフタクティック ボリプロピレンー四塩化炭素系について得た $x_{12}=0.113$ $\exp \left[1.879 v_{\text {g }}\right]$ を用いた。

表 4より明らかなよ5に, 非晶鎖長は $\mathrm{S}>\mathrm{R}>\mathrm{I}$ の順に 减少している。非晶鎖長の低滅と共に，高分子鎖の回転 運動は束槕され，それに伴ってセグメントの協同運動性 も低下するであるう。架橋高分子の $T_{g}$ と比容に関する Fox-Loshaekの理論 ${ }^{88)}$ によれば，架橋密度の增加(従 って $\bar{M}_{c}$ の减少) と共に $T_{g}$ は增大し体膨張係数が減少す るとされて扔り、こ机はセグメントの協同運動性低下を 意味すると考元られる。

表 2 に括いて，I，R，S陚料の主分散温度 $\left(T_{g}\right.$ に対応 


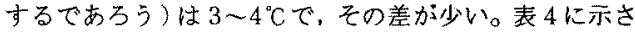
れた程度の $\bar{M}_{a}$ に扔ける相対的变化は，あまり $T_{g}$ に影響 しないのか，又は粘弾珄测定時の精度，再現珄からして， それ程鋭敏にT の差巽が見出世ないのか現段階では不 明であるが，I，R，S間に招いて著しくT $T_{g}$ が翼る事は ないと考える。

さて，藤田は無定形高分子の自由体皘分率 $(f)$ と, へ ネトラントの抬散係数 $(D)$ の関係を次式で表わした ${ }^{28)} 。$

$$
D=D_{0} \exp \left[-\frac{B d}{f}\right]
$$

$B d$ は前述の意味をもつ定数であり， $D_{0}$ は，ペネトラン トの形状等に依存する定数である。無定形高分子に対す る $f$ は。

$$
f=f_{g}+\alpha_{f}\left(T-T_{g}\right)
$$

とあらわされ， $f_{g}$ はがラス転移点において高分子が有 する自由体皘分率であり， $\alpha_{f}$ は $T_{g}$ 前後の体膨張保数差 である。一般に $f_{g}=0.025 ， \alpha_{f}=4.8 \times 10^{-4}\left(\mathrm{deg}^{-1}\right)$ 程 度の值をもつ ${ }^{37)}$ 。配向した結晶性高分子の非晶領域に （9）式を適用する際，(10) 式に抬ける定数が，無定形 高分子と同一の值をもつとする事には疑念があるが，ポ りエステル ${ }^{38}$ ，ナイロン等の結晶性高分子内に拉ける 染料の昇華桩散実験に扔いて，抬散保数の温度依存性は WLF型で整理し得るとの結果から判断して，結晶性高 分子の非晶領域に挍いてもその自由体磧瑥度後化は（10) 式と類似した形式により示され定数のみが異ると考えて よいであろう。(10) 式の定数を $f_{g}^{\prime} ， \alpha_{f}^{\prime}$ と書き換え,

$$
f=f_{g}^{\prime}+\alpha_{f}^{\prime}\left(T-T_{g}\right)
$$

とし，無定形高分子の場合同様に $f_{g}^{\prime}$ を結晶性高分子の $T_{g}$ における自由体積分率， $\alpha_{f}^{\prime}$ を $T_{g}$ 前後の体膨張係数差 とする。そして，染着非晶領域の配向度が等しいI， R， $\mathrm{S}$ 試料間の $\bar{M}_{c}$ の相殹が， $\alpha_{f}^{\prime}$ と $T_{g}$ に変化を生じ， $\bar{M}_{c} か ゙$ 小さくなると共に $\boldsymbol{\alpha}_{f}^{\prime}$ は隇少し $T_{g}$ は增加すると考えるな らば，拡散温度 $T$ は等しく $f_{g}^{\prime}$ も定であるので $f$ は全 体として低下する。（9）式に执ける $B d$ はこの場合一定 $(B d=2.25)$ であるから，Dは $f$ を介して $\bar{M}_{0}$ の変化と共

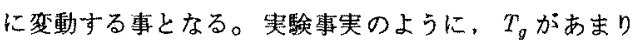
大きく変化しなければ， $\bar{M}_{c}$ と共に $\alpha_{f}^{\prime} か ゙$ 相対的に大きく 变化している穣が予想される。いずれにせよ，I，R，S 間の拡散倸数の美異は，PP非晶領域の $\bar{M}_{0}$ が変化する事 により，自由体積分率が異ってくる事に㷌因するものと 推察される。

I， R，S 試料中の非晶鎖長が変化する理由としては， 前節において議論された如く，収繀熱姏理，膨潤熱奶理 を行う事によって，染着非晶領域の結節点が解離される

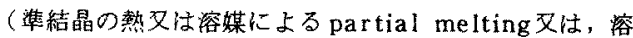
媒によるエンタングルメントのときほぐしなど)ためと
考えられる。非晶鎖長が増大する結果， $M_{0}, M_{\infty}$ む若干 增大するのであるう。落合ら 温度 $\left(60 \sim 150^{\circ} \mathrm{C}\right)$ にて熱処理する摖，熱処理温麻の高 い程非晶長が増大する事を諗め，熱如理によって不安定 な凖結晶が部分融解するものと推定している。このよう な見解は，延伸 P Pに対する金綱ら ${ }^{2 B)} の$ 熱解析結果と符 合し，著者らの桩散現象に対する解釉と矛盾するもので はない。

图 11 kは $\mathrm{I} ， \mathrm{R}, \mathrm{S}$ 試料系列の $f_{D}-v$ 関係を示した。

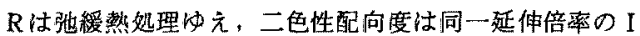
よりも若干低下していて，通常の結晶性ポリマーの熱収 縮に伴う非晶鎖熱緩和挙動により説明されると考える。 しかし，Sは約 $15 \%$ 自由取維しているにもかかわらず 逆に $f_{D}$ 憎大している。このような膨潤処理における 非晶鎖の異常配向性は，結晶領域の配向低下 (図9)と 関連していると考えられるが，現在の時点ではこれを形 態学的に説明する事注困奞である。この異常配向性は， 染料抬散に関する上記推諭を直接に妨げるむのではなか ろう。その成因並に分子諭的解秎に関しては，膨潤処理 に伴ら高分子鎖配向挙動についてのな拉詳細な检討が 必要と思われる。

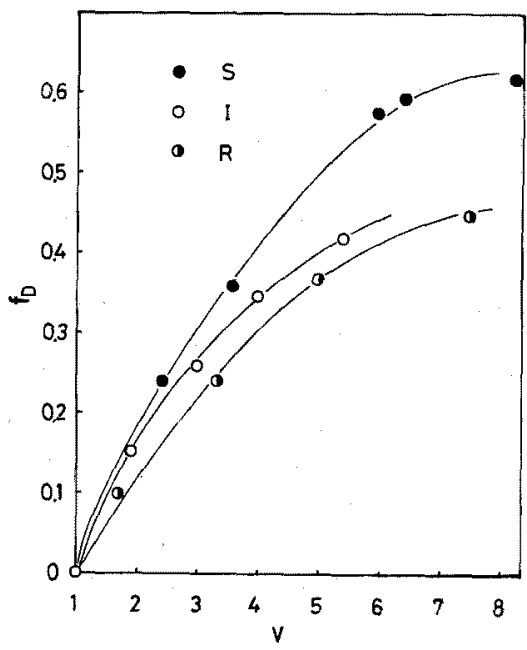

Fig. 11 Dichroic orientation factor of C.I. Disperse Yellow 7 in polypropylene film as a function of draw ratio. $I, R$ and $S$ are noted in the caption in figure.

\section{4. 総 括}

熱延伸したポリプロピレンフィルム中に拈けるC. I. Disperse Yellow 7 の拡散性を検討し, 次のような結 果を得た。 
(1) PPフィルムの延伸倍增大と共に，その中での 染料払散性が低下古る事を確認し，その抬散係数減少の 配向依存性は二色性配向係数に対しほぼ萑線的となる事 が種々の熱処理を行った試料系列において見出された。

（2）二巴性配向俰数がほとんど同一の值を示しても， 試料の延伸温度, 熱収樎、䀝澖収維などの履歷により抬 散保数の異る場合のある事が判明し，特に収縮処理され

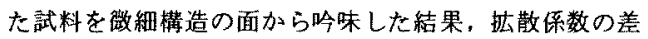
異は染着非晶領域の非晶鎖長变化に基づく自由体積分率 の変動に慢せられると推定した。

(3) PP-Yellow 7 系に拉いては，未延伸試料と延伸 試料の差、並に各種熱姐理条件の差にもかかからず，染 料払散に必要な臨界の自由体皘とミクロブラゥン運動に 要するセグメント䠛界体啨の比はほとんど一定で， $B d$ $=2.25$ となる。

付記：本研究について，熱心に御討諭いただいた本学 田中宏助教授、丁子敬子氏に深謝する。

(な㧍，本報の一部は、日本化学会東北支部大会( 昭 和 50 年 10 月，郡山了に扔て発表したものである。）

文献

1) A. R. Munden, H. J. Palmer, J. Text. Inst., 41, P609 (1950)

2) 清水 融, 宫崎宇一郎; 緎学誌, 14.557（1958）

3) Y. Takagi and H. Hattori, J. Appl. Polymer Sci, 9, $2167(1965)$

4) Y. Takagi, J. Appl. Polymer Sci, 9, 3887 (1965)

5) G. T. Davis and H. S. Taylor, Text. Res. J, 35, 405 (1965)

6) B. S. Sprague, J. Polymer Sci, C20, 159 (1967)

7) J. O. Warwicker, J.S. D. C., 303 (1970)

8) J.O. Warwicker, Brit. Polymer J., 3, 68 (1971)

9）森害弘司，頧田昌男，代田忠；絨学誌，21， $113(1971)$

10) G. Chantrey and I. D. Rattee, J. Appl. Polymer Sci, 18,93 (1974)

11）住田雅夫，日下部信幸，宮坂敬象，石川欣造；日 化, 1972,1165

12) D.C. Prevorsek, P.J. Harget, R.K. Sharma and A.C. Reimschuessel, J. Macromol. Sci.Phys., B8, 127 (1973)

13）岡島三郎，小林请二; 染色工業，12，43 (1964)

14) K. Nakayama, S. Okajima and Y. Kobayashi, $J$. Appl. Polymer Sci. 15, 1453 (1971)

15) I. Ito, S. Okajima and F. Shibata, J. Appl. Polymer
Sci, 14, $551(1970)$

16) T. Masuko, H. Tanaka and S. Okajima, J. Polymer Sci. A-2, 8, 1565 (1970)

17) S. Okajima, K. Kurihara and K. Homma, J. Appl. Polymer Sci., 11, 1703 (1967)

18) P. Corradini and M. Cesari, Atti Accad. Nazl. Lincei. Rend. Classe Sci. Fiz. Mat. Nat., 21, 365 (1956)

19) G. Farrow, Polymer, 2, 409 (1961)

20) L.E. Alexander, "X-ray Diffraction Methods in Polymer Science" 1st Ed., New York, John Wiley \& Sons, Inc., 1969

21) F. J. Balta-Calleja and A. Peterlin, J. Materials Sci., 4, 722 (1969); A. Peterlin and F. J. Balta-Calleja, J. Appl. Phys, 40, 4288 (1969); F. J. Balta-Calleja and A. Peterlin, J. Macromol. Sci-Phys., B4, 519 (1970)

22) H. Tanaka, T. Masuko and S. Okajima, J. Polymer Sci. A-1 7, 3351 (1969)

23) S. Okajima, N. Sato and M. Tasaka, J. Appl. Polymer Sci., 14, 1563 (1970)

24) A. Peterlin, J. Macromol. Sci.-Phys., B 1157 (1975)

25) 前田勝啓, 金網久明; 工化, 69，1789 (1966)

26) H. Tanaka, N. Takagi and S. Okajima, J. Polymer Sci. Polymer Chem. Ed., 12, 2721 (1974)

27）喜多村一夫。柴田二三男, 吉田善一; 織学誌, 27, 359 (1971)

28) H. Fujita, Fortschr. Hochpolym.-Forsch., 3, 1 (1961)

29) J.P. Bell, J. Appl. Polymer Sci, 12, 627 (1968)

30) J. H. Dumbelton, J. P. Bell and T. Murayama, $J$. Appl. Polymer Sci., 12, 2491 (1968)

31) J.P. Bell and T. Murayama, J. Appl. Polymer Sci., 12, $1795(1968)$

32）小林靖二, 染色加工第 120 委員会年次報告, 25， 135 (1973)

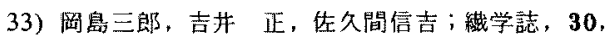
$\mathrm{T}-107(1974)$

34) P. J. Flory and J. Rehner, Jr., J. Chem. Phys., 11, $512,521(1943)$

35) H. Ochiai, K. Gekko and H. Yamamura, J. Polymer Sci., A-2, 9, 1629 (1971)

36) T. G. Fox and S. Loshaek, J. Polymer Sci, 15, 371 (1955)

37) M. L. Williams, R. F. Landel and J. D. Ferry, J.A.C.S., 77, 3701 (1955)

38) 酒井豊子，宮坂啓象，石川欣造，瀻学誌， 30, T 571 (1974)

39) 酒井豊子, 宮找啓象, 石川欣造; 絨学誌, 31, T 91 (1975) 